\title{
An Overview of the Persistent Organic Pollutants in the Freshwater System
}

\author{
M. Mosharraf Hossain ${ }^{1}$, K.M. Nazmul Islam ${ }^{1}$ and Ismail M.M. Rahman²* \\ Institute of Forestry and Environmental Sciences, University of Chittagong, Chittagong, \\ 2Department of Applied and Environmental Chemistry, University of Chittagong, \\ Chittagong, \\ Bangladesh
}

\section{Introduction}

Organic contamination can be viewed as the secondary and tertiary dispersions of organic compounds from various sources into the global circulation across different spheres of the environment viz. hydrosphere, lithosphere, atmosphere and biosphere - mediated primarily by human activities [1, 2]. Freshwater contamination occurs in diverse ways, of which, contamination by organic compounds of various kinds and traits from a wide range of sources is a major concern due to their persistent nature and harmful biological impacts, especially on human beings [3]. All over the world, supply of freshwater is shrinking in quantity and dwindling in quality [4] - forcing the modern city planners to recycle potable water from raw water coming out of waste treatment facilities [5]. Contaminants are coming into the fresh water streams from different natural and anthropogenic sources of which the anthropogenic contribution is getting larger in volume each day as do their diversity [6]. These contaminants are either attenuated naturally into less toxic or non-toxic forms [7], or they persist in the fresh water ecosystem for long time, enter the food chain through bioaccumulation and bio magnified to cause cascading effect on terrestrial and aquatic biodiversity altogether $[8,9]$. Presence of organic compounds and their harmful derivatives makes water unfit to consumption. Maintaining a supply of pure water for ever increasing population is already a daunting challenge all over the world while the organic contaminants are aggravating the challenges further [10, 11]. Hence, we need a clear understanding of the classes of organic compounds, which find their way into the fresh water system, their sources, and their transformation through physicochemical and biological processes in the fresh water system in order to control their entry and undesired transformation thereof. Moreover, we need to know the chemistry of these contaminants and their effects on the environment in general and on human health in particular while detecting their presence in fresh water in a quick and easy manner. Better understanding of these pollutants is inevitable for developing better techniques of purification of water from persistent organic contaminants. Substantial improvement has so far been achieved in all these aspects. This chapter is an effort to get a contemporary picture of our understanding

*Corresponding Author 
about the organic contaminants in the freshwater system. After introducing the issue of fresh water pollution in the second section, we shall intensely focus on different aspects of contamination of fresh water by persistent organic compounds in section three. In this section, we shall describe the categories of organic compounds which contribute to fresh water contamination with their sources, fate and effects. This section will also include a review of detection techniques available for the detection of organic contaminants in the freshwater system. The section will be concluded with two sub sections - one highlighting our understanding of the natural assimilation of persistent organic contaminants through normal aquatic ecological processes and the other focusing on the techniques that we have at our discretion for the removal of such contaminants from water in order to purify water. Different conventions and protocols are in place to reduce and control the issue of organic contamination of water. Before concluding the chapter, we shall try to shed some light on the current status of such protocols and conventions regarding organic contamination of fresh water.

\section{Pollution and contamination of fresh water}

Contamination of fresh water is a natural process; in the passage of the normal cycling of water through the water cycle, during precipitation, different organic substances of varied origins, both soluble and insoluble, get transported into fresh water streams. Among the natural contributors of organic contaminants, volcanic eruption, forest fires, natural decomposition of organisms, are substantial sources [4]. Organic substances of biological origin also result from either excreta or wastes from of living organisms, from municipal waste decomposition, etc. Among the dissolved organic substances in water, humic and fulvic substances, polycyclic aromatic hydrocarbons (PAHs), halogenated aromatic and aliphatic hydrocarbons, phthalate esters are the major classes [12]. However, the input of organic contaminants from natural sources does not increase the way they are increasing from anthropogenic sources. Human activities are increasing the consumption of the already known organic compounds all over the world for meeting diverse needs while organic pharmaceuticals, pesticides, paints and coloring materials, cosmetics, etc with novel properties are synthesized every day for many purposes. Consequently, the quantity and diversity of anthropogenic organic contaminants that enter the fresh water system and polluting it are accumulating. According to a recent study [6] on the presence organic contaminants in untreated drinking water sources in USA, for surface sources, natural sterol - cholesterol, herbicide - metolachlor, nicotine metabolite - cotinine, natural plant sterol - $\beta$ sitosterol and caffeine metabolite - 1,7-dimethylxanthine were the five most frequently detected organic contaminants. In ground water sources, solvent - tetrachloroethylene, pharmaceutical - carbamazepine, plasticizer - bisphenol-A, caffeine metabolite - 1,7dimethylxanthine, and fire retardant - tri (2-chloroethyl) phosphate were the five respective major contaminants. However, they could not establish any specific seasonal trends in the distribution patterns of contaminants.

\section{Organic contaminants in freshwater system}

In recent decades there has been escalating concern about the potential effects of the occurrence of a diverse array of organic contaminants in the fresh water system on the 
human and environmental health $[12,13]$. Organic contaminants are mostly human-induced chemicals entering into natural fresh water through pesticide use, industrial chemicals, and as by-products of degradation of other chemicals and persist long enough in the environment to cause harmful effects. They tend to accumulate in reservoirs such as water, soil, sediments etc. From these reservoirs, they are remobilized through various processes, switch form or speciation and become available to the biological food chain. In this way, these contaminants tend to bio accumulate and bio magnify exhibiting toxicity and other related outcomes - mutagenicity, carcinogenicity and teratogenicity - resulting into chronic and acute disorders [14].

\subsection{Common organic contaminants in freshwater}

Organic contaminants are composed basically of hydrocarbons both from anthropogenic and natural sources. Many contaminating hydrocarbons exist in the environment but carcinogens, mutagens and teratogens among them are the most closely monitored [15]. These contaminants enter the fresh water system both from point and non-point sources. Point sources are defined in a spatially explicit manner both in terms of chemical residues from organic contaminants they contribute and by epidemiological factors thereof, like morbidity, mortality or community disruption [16]. Effluents from municipal sewagetreatment plants, industrial sources, storm sewer systems, mining and construction sites, etc. are examples of point sources. In contrast, organic contaminants from non-point-sources are diffused over broad geographical scale in a relatively uniform environmental concentration explicitly delineated into spatial or temporal patterns. Consequently, the management of non-point organic contaminants is difficult. Among non-point-sources are agricultural runoff, urban runoff and atmospheric wet and dry depositions [17]. Based on how they are formed, organic contaminants of fresh water systems can be of two categories - natural and synthetic. Organic contaminants of biological origin are natural organic contaminants of which sugars, alkaloids and terpenoids are prominent. Synthetic organic contaminants are generated through reaction among different chemical species, which subsequently get discharged into the fresh water - examples include DDT, Polychlorinated biphenyls (PCBs), Chlordane, and Dieldrin, etc. [18]. Some organic contaminants are easily broken down upon entry into the environment, but others are very persistent, popularly termed as, Persistent Organic Pollutants (POPs) which are of particular concern because of the long term risks they pose. POPs, due to their persistent nature, become widely distributed geographically to pose adverse effects to human health and the environment [2]. The Stockholm Convention on POPs entered into force in 2004, and it identified some POPs potential for damaging environment and human health (Table 1).

Since the mid-twentieth century, pesticides became ominous in agriculture for saving crop yields from pastes both in the field and in storage. Pesticides are vital for crop protection and human health in many parts of the world $[19,20]$, yet due to their detrimental effects on natural ecosystems [21-23], we are becoming increasingly worried about their short and long term harms on the environment. A number of pesticides are in use throughout the world, but the four most important groups are insecticides, rodenticides, herbicides and fungicides each group contains a rapidly accumulating list of persistent organic compounds capable of contaminating fresh water. Upon application, a substantial amount of these chemicals found their ways into fresh water systems. Most of the pesticides tend to bioaccumulate and exert 
ruinous effects on environment and human health [24, 25]. Among the twelve toxic substances listed for being phased out as per the Stockholm Convention, nine are pesticides. The most common pesticide among the fresh water organic contaminants are DDT, Diedrin, Aldrin, Chlordane, Endrin, Mirex, Toxaphene, and Heptachlor [25, 26] - all of which has a long half-life, can break down to intermediate species and have detrimental health effects.

\begin{tabular}{ll}
\hline POPs & Class \\
\hline Heptachlor & Pesticide \\
Endrin & Pesticide \\
Dieldrin & Pesticide \\
Aldrin & Pesticide \\
Chlordane & Pesticide \\
Hexachlorobenzene & Pesticide / industrial chemical / by-product \\
Dioxins & By-product \\
Furans & By-product \\
Polychlorinated biphenyls (PCBs) & Industrial chemical / by-product \\
DDT & Pesticide \\
Mirex & Pesticide \\
Toxaphene & Pesticide \\
\hline
\end{tabular}

Table 1. POPs scheduled to be phased out and eliminated under the Stockholm Convention, 2004.

\subsection{Sources of persistent organic contaminants in the freshwater system}

\subsubsection{Industrial sources}

Poly Aromatic Hydrocarbons (PAHs) are produced through burning of common fossil fuels, such as coal, petroleum and natural gas as well as from biomass fuels such as fuel wood, animal excreta etc. Naphthalene, an ingredient in dyeing industry, aluminium smelting industry and lubricant oils as well as wood procession industry, enters into water, mainly through discharges and spills during the storage, transportation and disposal of fuel oil and coal tar and incomplete combustion of organic compounds [27]. Anthracene releases from dye and pesticide manufacture, from exhaust of engines, from the incomplete combustion of organic compounds [28]. Burning of gasoline, garbage or biomass causes release of benzopyrene into the environment. It also releases from burning of tar during road construction, from wood preservative creosote and from glues used in electrical components [29]. The environmental release of benzene occurs from industries such as rubber processing, dyeing and washing, pharmaceuticals, and agrochemicals. Underground gasoline storage tanks also leak benzene into ground water [30]. Xylene is a common solvent, thinning and cleaning agent used widely in printing, rubber, wood processing, plastic and leather industries. Being liquid in form, xylene easily leaks into surface or ground water [31]. Dioxins are another class of organic contaminants released from pulp and paper mills, wood preservatives, etc. Trichloroethene is used as solvent during cleaning engine parts from grease and spillage of it to environment occurs during cleaning process or from the wastes of such cleaning facilities. 


\subsubsection{Agricultural and farming sources}

Agrochemicals are predominantly organic in nature and diverse in classes, nature and applications. They constitute the major anthropogenic source of organic contaminants into the fresh water system [32]. Usually, agrochemicals when applied in agricultural field or agro-product storage or processing, come in direct contact with flow of fresh water and can contaminate gradually both the surface and ground sources of fresh water. As they enter through flow water, they can reach unimaginable distance from the place of their applications.

\subsubsection{Natural sources}

The background concentration of organic contaminants in the environment is negligible, however, a number of them exist in the environment. Some of the organic contaminants enter the environment through various natural processes [1] such as volcanic eruptions, forest fires, biological decomposition and microbial activities. PAHs may enter the fresh water system naturally from thermal geological reactions, i.e. volcanic eruptions, forest fires, etc. Anthracene releases from natural sources such as coal and tar, can seep into the ground and surface water from coal piles. Among seventy five dioxins, originating naturally from volcanic eruption or forest fires, 2,3,7,8- tetrachlorodibenzo- $p$-dioxin (TCDD), is the most contaminating to the environment. A deeper treatment of contaminant contribution from natural sources has been discussed elsewhere [32].

\subsubsection{Domestic and municipal sources}

Burning of biomass fuels, such as wood, leaves, cow dung, etc., lead to the release of organic contaminants such as PAHs, anthracene and benzopyrene, which ultimately reaches water or soil [33]. Burning of coal for cooking and home heating is another source of anthracene and benzopyrene, which find their way into the fresh water system. One of the major concerns of modern city or municipality management is the vast quantity of solid wastes produced every day in big municipal cities. The solid waste stream contains a huge amount of organic substances - human and animal excreta and wastes, vegetable and food remaining, healthcare wastes, etc. Upon their disposal into land filling or open dumping ground, the leachates thereof easily finds their way into surface or ground water [34]. Rich in organic contaminants for fresh water system, the leachates either contaminates surface water in the short run and ground water gradually, in the long run. Incineration of municipal waste also releases different organic contaminants into the air which ultimately pollute fresh water. In 37 rivers of Japan, presence of many pharmaceutical organic compounds has been found of which crotamiton, carbamazepine, ibuprofen and mefenamic acid were positively correlated to population in the respective catchment areas indicating the contribution of these compounds from sewage sources [35].

\subsubsection{Atmospheric deposition}

Organic contaminants from different sources easily enter to the atmosphere and subsequently adsorbed with atmospheric particles or moisture. Such deposition of contaminants from the atmosphere ultimately reaches the aquatic ecosystem. An example of atmospheric movement of organic contaminants to fresh water ecosystem has been clearly 
demonstrated in case of two high arctic lake systems - Lake Ellasjøen and Lake Øyangen which are $500 \mathrm{~km}$ away from known point source [36]. In sediments and biota from both the lakes, high levels of POPs especially PCB and $p, p$ 9-DDE, have been detected. However, the higher levels of these contaminants in Lake Ellasjøen has been linked to the higher precipitation it receives, and that it receives POPs from birds that use the lake as resting ground.

\subsection{Fate of organic contaminants}

Organic contaminants usually break down easily in the environment through natural assimilative processes, but there are compounds highly resistant and these needs special attention from the standpoint of pollution of fresh water systems. Popularly known as Persistent Organic Pollutants (POPs), they remain in the environment from many months to even years [1].

\subsubsection{The media involved in the aquatic transport of organic chemicals}

Some of the persistent organic contaminants, including DDT, move from the point of application through the atmosphere and translocate from relatively warm regions to get condensed at colder, higher latitudes through a process known as global distillation effect. This explains the deposition of organic compounds at high concentrations in the Arctic region which is free from usage of such compounds $[9,37]$. Benzene is water soluble, to some extent, and can seep into groundwater as well. Among the POPs, polychlorinated biphenyles (PCBs) were wonder materials with a wide range of applications. However, they entered the fresh water system during their manufacture and use. Even after the ban on them, they are still entering into the environment from the waste products where PCBs were used in the past. In fresh surface water or ground water, most of the PCBs adhere, weakly or strongly, to suspended sediment particles and remain as such for years [38]. Sediments containing PCB settle down to the bottom of fresh water reservoirs. Such sediments become the source of PCBs and gradually but continuously release PCBs in scanty amounts for years.

\subsubsection{Bio-transformation and bio-accumulation}

POPs are less soluble in water and more in lipid or fat resulting in their higher accumulation into the fatty tissues of living organisms. These organic contaminants enter living organisms from water through drinking of contaminated water or through ingestion of foods either processed using such water or foods from sources, which already have accumulated these contaminants. Bioaccumulating POPs include pesticides, PCBs, dioxins, and furans [1]. Repeated intake of organic contaminants or food contaminated thereof may cause biomagnification of these contaminants leading to the enhancement of the harm caused by these contaminants. The example of this is DDT, which shows higher concentration in fish fat tissue compared to its concentration in water where fishes grow. Different derivatives of DDT, for example, DDE or DDD forms inside the organisms and they are excreted off through excreta, but they may excrete through milk of mammals leading to transfer of them to offspring from parents. These compounds are stored most readily in fatty tissue. The tendency of these substances to persist in the environment and to be build-up in plant and animal tissues poses the greatest risk to human health and the environment. Usually, the 
organic contaminants function as mutagenic, carcinogenic or teratogenic agents. Benzene, in fresh water, breaks down quickly and does not build-up in plants or animals. Fat soluble dioxins bioaccumulate easily in fatty tissue as well as in skin, muscle and other organs of most of the exposed animals, including fishes grown in dioxin rich surface water sources. The risk is higher for fishes from streams where affluent from paper and pulp industry is released.

\subsection{Effect of fresh water organic pollutants}

DDT causes sperm decline, eggshell thinning of birds and birth defects in many animals, which have been linked to near elimination of some species of animal. Bald eagle, a carnivore, is an example of what damage a POP like DDT can do [1]. On the other hand, PCBs from fresh water bioaccumulate into fish to a concentration hundreds or thousands of times higher than their levels in water. Benzene, if ingested, is broken down into secondary metabolites in the liver and bone marrow which are suspected to have to link with liver and bone marrow tissues. Exposure to moderate or high toluene levels has potential adverse effects on their liver, kidneys, and lungs. Aquatic animals absorb only a minimal amount of the xylene available in water contaminated with it. However, methylbenzaldehyde, a breakdown product from xylene cause damage to lungs of some animals. Exposure of animals to moderate to high levels of trichloroethane (TCE) causes liver and kidney damage.

Among the organic contaminants, PCBs, DDT, DDE, DDD, naphthalene, benzopyrene, dioxins, etc., are reported or suspected carcinogens for humans. Benzopyrenes have been related to the production of metabolites doubted as a carcinogen precursor. PCBs enter the human body through eating of PCB containing meat or fish and get converted to other metabolites some of which excreted naturally, but others stay in fat and in the liver for months or years. Inclusion of PCBs into breast milk fat and their subsequent entries into babies have been reported $[8,39,40]$. In Western Japan, the consumption of rice bran oil contaminated with some thermal degradation products of PCBs, i.e. furans and quaterphenyls, which are more toxic than PCBs, led to a severe form of acne called chloracne followed by fatigue, nausea, and liver disorders [41, 42]. Short-term low human exposure to naphthalene in mild concentration has been linked to eye and skin irritation while at elevated exposure levels, it causes headaches, fatigue and nausea. However, ingestion of naphthalene may cause hemolytic anemia, damages to kidneys and liver. Decreasing fertility, fatal damage, lung and skin tumors are also evident in the case of chronic exposure to naphthalene. Trace amount of dioxins at parts per trillion levels may cause hormone disruption; it also causes numbness, fluctuations in liver enzymes levels, nausea, etc. Exposure to large quantity of TCE creates dizziness to senselessness and even death. Range of concentrations of different pharmaceutical organic contaminants of fresh water in water bodies around the world, their lowest predicted no-effect concentrations (PNEC), their health effects at higher doses along with natural attenuation have been summarized by Pal et al. [2].

In a high-latitude freshwater food web of a remote lake in the Canadian Arctic, bioaccumulation of atmospherically deposited organochlorides such as PCBs, DDT, chlordane (CHL)-related compounds and hexachlorocyclohexane $(\mathrm{HCH})$ - isomers were found at ng $\mathrm{L}^{-1}$ concentrations in water and sediment samples, while in fish samples, 6- to 10-fold higher concentrations of these POPs compared to water samples were observed [9]. 
Every day, the flow of organic contaminants into the fresh water system is increasing with the increase in the industrial activities and intensification of agricultural practices alongside the expansion of big municipalities all over the world. The rapid growth of population and the changes in lifestyle is enhancing the demand for global freshwater consumption. Hence, the necessity of treating larger volume of water is increasing and the task of meeting this demand is becoming complicated in terms of technology and costlier in terms of capital investment due to increased flow of contaminants in a larger variety into the water. The challenges that the water treatment will face in near future have been discussed in a nice review by Shannon et al. [43].

\subsection{Detection of organic contaminates in fresh water system}

\subsubsection{Instrumental and laboratory techniques}

The ubiquitous presence of persistent organic pollutants in surface and ground water sources necessitates their detection at trace level in order to ensure safe drinking water standards for public health in one hand and to develop appropriate technology for the removal or avoidance of these contaminants, on the other hand. Significant efforts are evident to the development of novel techniques and systems for the detection of the presence of organic fresh water contaminants in sub parts per billion levels to sub parts per trillion levels along with the refinement of existing detection capabilities for these organic compounds in the environment [6]. Pressurized solvent extraction, solid phase extraction, and capillary-column gas chromatography/mass spectrometry techniques has been developed for the determination of organic contaminants [44, 45]. Gas chromatographyhigh resolution mass spectroscopy (GC-HRMS) has been used in Canada to detect estrogenic organic fresh water contaminants in municipal wastewater as well as in effluents from bleached kraft pulp mill at ng $\mathrm{L}^{-1}$ level [46]. Natural organic matter and the anthropogenic organic contaminants have distinct fluorescence signatures, which have been used to develop a technique for early detection of contamination in a groundwater based drinking water supply plant [47]. Very recently, low cost calibration free methods for determination of organic contaminants have been reported [48].

\subsubsection{Bio indicators}

Bio monitoring of water contamination using bio indicators is becoming a cost-effective mode of contamination detection in aquatic systems $[49,50]$. Some species of aquatic biota helps the depuration of aquatic resources contaminated by organic contaminants through bioaccumulation. The presence and concentration of contaminants can therefore be biomonitored by using these species as biological indicators. Bivalves are usually preferred as a bio indicator and Goldberg in 1975 introduced the concept of "Mussel Watch" followed by the wide use of bivalves as an ideal bio-monitor in routine monitoring for National and Regional programmes [51]. The current results from the implementation of this approach succeeded to identify hot spots of contaminants and in following up their spatial distribution in the marine environments. "Mussel Watch" approach is based simply on using the characteristic feeding habits of bivalves as filter feeders which can accumulate tremendous quantity of contaminants in their tissues; reflecting the present quality and quantity of bio-available chemicals in their surrounding waters. The approach has been used to monitor PCBs in water [52], organotin contamination of fresh water lakes [53], and 
for other organic contamination issues [54,55]. Diatoms are also used in bio monitoring of water contamination [56].

\subsubsection{Assimilative capacity of water and organic contaminants}

Once into the fresh water system, the natural assimilative capacity of water can attenuate majority of the organic compounds in a relatively shorter period of time using natural processes such as biotransformation, photolysis, sorption, volatilization, and dispersion, or a combination thereof [57]. The completion of natural breakdown of PCBs in the water may take several years, or even decades. Benzopyrenes, once get into the fresh water system, is either photo-degraded at the surface of waters or biodegraded gradually, however, their adsorption to particulates slows down the rate of natural assimilation. After entry, xylene may remain in fresh water for months or more but it gradually breaks down into relatively less harmful or harmless organics [58]. Trichloroethane and other halogenated hydrocarbons degrade naturally by photo-oxidation and biodegradation. In surface water, natural breakdown occurs in weeks while in groundwater, the breakdown is much slower. However, the slow rate of desorption and resorption of trichloroethane in subsurface soil make their long persistence in soil from where they may find their way into ground water for a quite long time [59]. Reports on the natural attenuation of pharmaceutical organic compounds in the fresh water system have been reviewed in an excellent review by Pal et al. [2]. New approaches are emerging to assess the natural attenuation of organic contaminants in the freshwater system. Plume-scale electron and carbon balances have been used in UK in a Permo-Triassic Sandstone aquifer contaminated with phenolic compounds [7].

\subsection{Treatment options for organic contaminants in freshwater system}

The entry of organic contaminants into ground and surface fresh water source is increasing with industrialization and rapid urbanization. Accordingly, efforts towards the enhancement of treatment capabilities are increasing [60]. Bolong et al. [61] has reviewed the use and efficiencies of activated carbon, oxidation, activated sludge, nanofiltration and reverse osmosis membranes in removal of persistent organic contaminants. The current options for water treatment for the removal of organic contaminants are based on continued development of activated sludge method, which is basically a bio transformation method [62, 63], the membrane filtration methods [60, 64] and reverse osmosis [65-67]. Activated sludge with zeolite improves organic contaminants biodegradability during anaerobic oxidation of municipal waste water by increasing the number of heterotropic bacteria as high as 55 times compared to control activated sludge [68]. With the use of zeolite, the COD removal rate reached to about $90 \%$ while the TOC removal rates with $0.22 \mu \mathrm{m}$ and $0.45 \mu \mathrm{m}$ filter membrane reached respectively at $97 \%$ and $92 \%$. The sludge with zeolite can depredate further organic contaminants, which was difficult to degrade using organisms. Removal of organic contaminants are also enhanced by using novel biodegradable coagulants like chitosan, poly-lactic acid derivatives, etc. [69], and adsorption into porous materials such as the activated charcoal [70], or granular carbon [71], etc. The focuses of these techniques are basically on the removal of POPs from freshwater entering into the environment through industrial or municipal effluents, since 
it became a binding requirement for business entities in almost all the countries of the world to release industrial effluents after making it free from such contaminants, which made the development of modern and effective removal technology an active field of research with adequate funding. However, there is a grim picture even after all these developments, as a recent report from South-East Queensland, Australia reported the presence of a total of 15 organic contaminants, including NDMA and bisphenol in potable water recycled from raw water coming off waste treatment plants with reverse osmosis equipped advanced water treatment facility [5]. On the other hand, the need for removal of organic contaminants puts tremendous pressure on the water-treatment facilities in terms of increased cost. However, some alternatives are emerging in this case as well to bring the cost of treatment down. Low-cost alternative adsorbents (LCAs), which comprise of both natural and synthetic materials, are in use for removal of POPs. LCAs have shown fast kinetics and appreciable adsorption capacities in removing organic dyes from the contaminated fresh water [72].

\section{Convention/protocol on organic contaminant of fresh water}

There are a number of conventions and protocols dealing with the issue of organic contaminants of the fresh water system, however, none of these protocols specifically deals only with this issue. The progress is in place, and we can expect that in the years to come, specific global convention covering the range of organic pollutants of the fresh water system will be adopted and ratified by all. Among the current conventions and/or protocols, Stockholm Convention on Persistent Organic Pollutants comprises of 173 parties, and it entered into force in 2004. The convention deals with POPs and it has identified 12 highly hazardous organic compounds, mostly agrochemicals and outlined the phasing out of these twelve gradually by ratifying parties [61]. Convention on the Protection and Use of Transboundary Watercourses and International Lakes, adopted at Helsinki, in 1992 by United Nations Economic Commission for Europe (UNECE), outlines the protocols for controlling trans-boundary movement of contaminants [73]. There are many country or region-specific regulations and directives related to water quality, which also covers the issue of organic contaminants of the freshwater system.

\section{Conclusion}

Our understanding of the extent to which organic contaminants are entering into the freshwater system is still sketchy, as do our knowledge of the subsequent chemistry of these contaminants - their fate, effect and mediation. The reasons of non-comprehensive understanding are many. The first is the impossibility, in practice, to keep a clear accounting of the entry of persistent organic contaminants into the aquatic system since the entry is taking place through plethora of means from innumerable sources. Secondly, the rapid increment of the pool of persistent organic fresh water contaminants in number and diversity; the interaction among the organic contaminants themselves, between contaminants and aquatic environment mediated by biological, physical and chemical forces leading to the formation of many intermediates and derivatives thereof. However, new information is added to our knowledge base each day, and we are becoming more capable of addressing the issue - locally and globally. 


\section{References}

[1] T. Navratil and L. Minarik, Trace elements and contaminants, In: V. Cilek and R. H. Smith (Eds.), Encyclopedia of Life Support System, Vol. IV, pp. 1184-1213, 2005.

[2] A. Pal, K.Y.-H. Gin, A.Y.-C. Lin and M. Reinhard, "Impacts of emerging organic contaminants on freshwater resources: Review of recent occurrences, sources, fate and effects", Science of the Total Environment, Vol. 408, pp. 6062-6069, 2010.

[3] I. Rostami and A.L. Juhasz, "Assessment of persistent organic pollutant (POP) bioavailability and bioaccessibility for human health exposure assessment: A critical review", Critical Reviews in Environmental Science and Technology, Vol. 41, pp. 623-656, 2011.

[4] R.P. Schwarzenbach, T. Egli, T.B. Hofstetter, U. von Gunten and B. Wehrli, "Global water pollution and human health", Annual Review of Environment and Resources, Vol. 35, pp. 109-136, 2010.

[5] D.W. Hawker, J.L. Cumming, P.A. Neale, M.E. Bartkow and B.I. Escher, "A screening level fate model of organic contaminants from advanced water treatment in a potable water supply reservoir", Water Research, Vol. 45, pp. 768-780, 2011.

[6] M.J. Focazio, D.W. Kolpin, K.K. Barnes, E.T. Furlong, M.T. Meyer, S.D. Zaugg, L.B. Barber and M.E. Thurman, "A national reconnaissance for pharmaceuticals and other organic wastewater contaminants in the United States-II) Untreated drinking water sources", Science of the Total Environment, Vol. 402, pp. 201-216, 2008.

[7] S.F. Thornton, D.N. Lerner and S.A. Banwart, "Assessing the natural attenuation of organic contaminants in aquifers using plume-scale electron and carbon balances: model development with analysis of uncertainty and parameter sensitivity", Journal of Contaminant Hydrology, Vol. 53, pp. 199-232, 2001.

[8] N.M. Tue, A. Sudaryanto, T.B. Minh, T. Isobe, S. Takahashi, P.H. Viet and S. Tanabe, "Accumulation of polychlorinated biphenyls and brominated flame retardants in breast milk from women living in Vietnamese e-waste recycling sites", Science of the Total Environment, Vol. 408, pp. 2155-2162, 2010.

[9] K.A. Kidd, R.H. Hesslein, B.J. Ross, K. Koczanski, G.R. Stephens and D.C.G. Muir, "Bioaccumulation of organochlorines through a remote freshwater food web in the Canadian Arctic", Environmental Pollution, Vol. 102, pp. 91-103, 1998.

[10] C. Chen, X. Zhang, W. He, W. Lu and H. Han, "Comparison of seven kinds of drinking water treatment processes to enhance organic material removal: A pilot test", Science of the Total Environment, Vol. 382, pp. 93-102, 2007.

[11] J.D. Wilcox, J.M. Bahr, C.J. Hedman, J.D.C. Hemming, M.A.E. Barman and K.R. Bradbury, "Removal of organic wastewater contaminants in septic systems using advanced treatment technologies", Journal of Environmental Quality, Vol. 38, pp. 149156, 2009.

[12] H.F. Al-Mudhaf, F.A. Alsharifi and A.S. Abu-Shady, "A survey of organic contaminants in household and bottled drinking waters in Kuwait", Science of the Total Environment, Vol. 407, pp. 1658-1668, 2009.

[13] R. Loos, B.M. Gawlik, G. Locoro, E. Rimaviciute, S. Contini and G. Bidoglio, "EU-wide survey of polar organic persistent pollutants in European river waters", Environmental Pollution, Vol. 157, pp. 561-568, 2009. 
[14] K.K. Barnes, D.W. Kolpin, E.T. Furlong, S.D. Zaugg, M.T. Meyer and L.B. Barber, "A national reconnaissance of pharmaceuticals and other organic wastewater contaminants in the United States-I) Groundwater", Science of the Total Environment, Vol. 402, pp. 192-200, 2008.

[15] M.S. Evans, D. Muir, W.L. Lockhart, G. Stern, M. Ryan and P. Roach, "Persistent organic pollutants and metals in the freshwater biota of the Canadian Subarctic and Arctic: An overview", Science of the Total Environment, Vol. 351-352, pp. 94-147, 2005.

[16] A. Kronimus, J. Schwarzbauer, L. Dsikowitzky, S. Heim and R. Littke, "Anthropogenic organic contaminants in sediments of the Lippe river, Germany", Water Research, Vol. 38, pp. 3473-3484, 2004.

[17] I. Baranowska, H. Barchańska and A. Pyrsz, "Distribution of pesticides and heavy metals in trophic chain", Chemosphere, Vol. 60, pp. 1590-1599, 2005.

[18] Z.L. Zhang, H.S. Hong, J.L. Zhou, J. Huang and G. Yu, "Fate and assessment of persistent organic pollutants in water and sediment from Minjiang River Estuary, Southeast China", Chemosphere, Vol. 52, pp. 1423-1430, 2003.

[19] D.G. Hela, D.A. Lambropoulou, I.K. Konstantinou and T.A. Albanis, "Environmental monitoring and ecological risk assessment for pesticide contamination and effects in Lake Pamvotis, northwestern Greece", Environmental Toxicology and Chemistry, Vol. 24, pp. 1548-1556, 2005.

[20] P. Mineau, "A review and analysis of study endpoints relevant to the assessment of "long term" pesticide toxicity in avian and mammalian wldlife", Ecotoxicology, Vol. 14, pp. 775-799, 2005.

[21] C.A. Laetz, D.H. Baldwin, T.K. Collier, V. Hebert, J.D. Stark and N.L. Scholz, "The synergistic toxicity of pesticide mixtures: Implications for risk assessment and the conservation of endangered Pacific salmon", Environmental Health Perspectives, Vol. 117, pp. 348-353, 2008.

[22] M. Olsson, A. Bignert, J. Eckhéll and P. Jonsson, "Comparison of temporal trends (1940s-1990s) of DDT and PCB in Baltic sediment and biota in relation to eutrophication", AMBIO: A Journal of the Human Environment, Vol. 29, pp. 195-201, 2000.

[23] A. Baun, N. Bussarawit and N. Nyholm, "Screening of pesticide toxicity in surface water from an agricultural area at Phuket Island (Thailand)", Environmental Pollution, Vol. 102, pp. 185-190, 1998.

[24] W. Lopes Soares and M. Firpo de Souza Porto, "Estimating the social cost of pesticide use: An assessment from acute poisoning in Brazil", Ecological Economics, Vol. 68, pp. 2721-2728, 2009.

[25] L.C.M. Cuyno, G.W. Norton and A. Rola, "Economic analysis of environmental benefits of integrated pest management: A Philippine case study", Agricultural Economics, Vol. 25, pp. 227-233, 2001.

[26] J. Fernandez-Cornejo, S. Jans and M. Smith, "Issues in the economics of pesticide use in agriculture: A review of the empirical evidence", Review of Agricultural Economics, Vol. 20, pp. 462-488, 1998.

[27] J.K. Rosenfeld and R.H. Plumb, "Ground water contamination at wood treatment facilities", Ground Water Monitoring \& Remediation, Vol. 11, pp. 133-140, 1991. 
[28] D.H. Thomas and J.J. Delfino, "A gas chromatographic/chemical indicator approach to assessing ground water contamination by petroleum products", Ground Water Monitoring $\mathcal{E}$ Remediation, Vol. 11, pp. 90-100, 1991.

[29] G. Chao and H. Ting-lin, Comparative research on petroleum composition between pro-release and post-release at the low petroleum contaminant sediments, In: International Symposium on Water Resource and Environmental Protection (ISWREP), Xi'an, 2011.

[30] O. Adeyemi, J.O. Ajayi, A.M. Olajuyin, O.B. Oloyede, A.T. Oladiji, O.M. Oluba, I.A. Ololade and E.A. Adebayo, "Toxicological evaluation of the effect of water contaminated with lead, phenol and benzene on liver, kidney and colon of Albino rats", Food and Chemical Toxicology, Vol. 47, pp. 885-887, 2009.

[31] R. Kandyala, S.P.C. Raghavendra and S.T. Rajasekharan, "Xylene: An overview of its health hazards and preventive measures", Journal of Oral and Maxillofacial Pathology: JOMFP, Vol. 14, pp. 1-5, 2010.

[32] S. Vedal, Natural sources - wildland fires and volcanoes, In: S. Tarlo, P. Cullinan and B. Nemery (Eds.). Occupational and Environmental Lung Diseases, John Wiley \& Sons, Ltd: Chichester, pp. 389-404, 2010.

[33] A. Asa-Awuku, A.P. Sullivan, C.J. Hennigan, R.J. Weber and A. Nenes, "Investigation of molar volume and surfactant characteristics of water-soluble organic compounds in biomass burning aerosol", Atmospheric Chemistry and Physics, Vol. 8, pp. 799-812, 2008.

[34] D. Barceló and M. Petrovic, Emerging contaminants from industrial and municipal waste: Occurrence, analysis and effects. Springer Verlag: Berlin, 2008.

[35] N. Nakada, K. Kiri, H. Shinohara, A. Harada, K. Kuroda, S. Takizawa and H. Takada, "Evaluation of pharmaceuticals and personal care products as water-soluble molecular markers of sewage", Environmental Science $\mathcal{E}$ Technology, Vol. 42, pp. 6347-6353, 2008.

[36] A. Evenset, G.N. Christensen, T. Skotvold, E. Fjeld, M. Schlabach, E. Wartena and D. Gregor, "A comparison of organic contaminants in two high Arctic lake ecosystems, Bjørnøya (Bear Island), Norway", Science of the Total Environment, Vol. 318, pp. 125141, 2004.

[37] G.A. Stern, E. Braekevelt, P.A. Helm, T.F. Bidleman, P.M. Outridge, W.L. Lockhart, R. McNeeley, B. Rosenberg, M.G. Ikonomou, P. Hamilton, G.T. Tomy and P. Wilkinson, "Modern and historical fluxes of halogenated organic contaminants to a lake in the Canadian arctic, as determined from annually laminated sediment cores", Science of the Total Environment, Vol. 342, pp. 223-243, 2005.

[38] G. Welfinger-Smith and D.O. Carpenter, Addressing sources of PCBs and other chemical pollutants in water, In: J. M. H. Selendy (Ed.). Water and Sanitation-Related Diseases and the Environment, Wiley-Blackwell: Hoboken, N.J., pp. 359-384, 2011.

[39] L.-M.L. Toms, L. Hearn, K. Kennedy, F. Harden, M. Bartkow, C. Temme and J.F. Mueller, "Concentrations of polybrominated diphenyl ethers (PBDEs) in matched samples of human milk, dust and indoor air", Environment International, Vol. 35, pp. 864-869, 2009.

[40] P.O. Darnerud, "Toxic effects of brominated flame retardants in man and in wildlife", Environment International, Vol. 29, pp. 841-853, 2003. 
[41] C.J. George, G.F. Bennett, D. Simoneaux and W.J. George, "Polychlorinated biphenyls a toxicological review", Journal of Hazardous Materials, Vol. 18, pp. 113-144, 1988.

[42] G. Ross, "The public health implications of polychlorinated biphenyls (PCBs) in the environment", Ecotoxicology and Environmental Safety, Vol. 59, pp. 275-291, 2004.

[43] M.A. Shannon, P.W. Bohn, M. Elimelech, J.G. Georgiadis, B.J. Marinas and A.M. Mayes, "Science and technology for water purification in the coming decades", Nature, Vol. 452, pp. 301-310, 2008.

[44] M.R. Burkhardt, Determination of wastewater compounds in sediment and soil by pressurized solvent extraction, solid-phase extraction, and capillary-column gas chromatography/mass spectrometry [electronic resource]. U.S. Dept. of the Interior, U.S. Geological Survey: Reston, Va., 2006.

[45] J.D. Cahill, E.T. Furlong, M.R. Burkhardt, D. Kolpin and L.G. Anderson, "Determination of pharmaceutical compounds in surface- and ground-water samples by solidphase extraction and high-performance liquid chromatography-electrospray ionization mass spectrometry", Journal of Chromatography. A, Vol. 1041, pp. 171-180, 2004.

[46] M.P. Fernandez, M.G. Ikonomou and I. Buchanan, "An assessment of estrogenic organic contaminants in Canadian wastewaters", Science of the Total Environment, Vol. 373, pp. 250-269, 2007.

[47] C.A. Stedmon, B. Seredyńska-Sobecka, R. Boe-Hansen, N. Le Tallec, C.K. Waul and E. Arvin, "A potential approach for monitoring drinking water quality from groundwater systems using organic matter fluorescence as an early warning for contamination events", Water Research, Vol. 45, pp. 6030-6038, 2011.

[48] A. Radu, S. Anastasova, C. Fay, D. Diamond, J. Bobacka and A. Lewenstam, Low cost, calibration-free sensors for in situ determination of natural water pollution, In: IEEE Sensors, Kona, HI 2010.

[49] W. Liu, L.Z. Shan, Q.L. Xie and others, "Application of biomonitoring in water pollution", Journal of Environment and Health, Vol. 25, pp. 456-458, 2008.

[50] Q. Zhou, J. Zhang, J. Fu, J. Shi and G. Jiang, "Biomonitoring: An appealing tool for assessment of metal pollution in the aquatic ecosystem", Analytica Chimica Acta, Vol. 606, pp. 135-150, 2008.

[51] E.D. Goldberg, V.T. Bowen, J.W. Farrington, G. Harvey, J.H. Martin, P.L. Parker, R.W. Risebrough, W. Robertson, E. Schneider and E. Gamble, "The mussel watch", Environmental Conservation, Vol. 5, pp. 101-125, 1978.

[52] A.A. Raeside, S.M. O'Rourke and K.G. Drouillard, "Determination of in situ polychlorinated biphenyl elimination rate coefficients in the freshwater mussel biomonitor Elliptio complanata deployed in the huron-erie corridor, southeast Michigan, USA, and southwest Ontario, Canada", Environmental Toxicology and Chemistry, Vol. 28, pp. 434-445, 2009.

[53] J. Yang, H. Harino, H. Liu and N. Miyazaki, "Monitoring the organotin contamination in the Taihu Lake of China by bivalve mussel Anodonta woodiana", Bulletin of Environmental Contamination and Toxicology, Vol. 81, pp. 164-168, 2008.

[54] S. Mishra, R.K. Mishra, B.K. Sahu, L. Nayak and Y. Senga, "Differential growth of the freshwater mussel, Lamellidens marginalis in relation to certain drugs", Environmental Toxicology, Vol. 23, pp. 379-386, 2008. 
[55] H. Liu, J. Yang and J. Gan, "Trace element accumulation in Bivalve Mussels Anodonta woodiana from Taihu Lake, China", Archives of Environmental Contamination and Toxicology, Vol. 59, pp. 593-601, 2010.

[56] A. Beyene, T. Addis, D. Kifle, W. Legesse, H. Kloos and L. Triest, "Comparative study of diatoms and macroinvertebrates as indicators of severe water pollution: Case study of the Kebena and Akaki rivers in Addis Ababa, Ethiopia", Ecological Indicators, Vol. 9, pp. 381-392, 2009.

[57] C.J. Gurr and M. Reinhard, "Harnessing natural attenuation of pharmaceuticals and hormones in rivers", Environmental Science \& Technology, Vol. 40, pp. 2872-2876, 2006.

[58] J.P. Barker, G.C. Patrick and D. Major, "Natural attenuation of aromatic hydrocarbons in a shallow sand aquifer", Ground Water Monitoring \& Remediation, Vol. 7, pp. 64-71, 1987.

[59] N.S. Thom, A.R. Agg and A.L. Downing, "The breakdown of synthetic organic compounds in biological processes", Proceedings of the Royal Society of London. Series B. Biological Sciences, Vol. 189, pp. 347-357, 1975.

[60] N. Tadkaew, M. Sivakumar, S.J. Khan, J.A. McDonald and L.D. Nghiem, "Effect of mixed liquor $\mathrm{pH}$ on the removal of trace organic contaminants in a membrane bioreactor", Bioresource Technology, Vol. 101, pp. 1494-1500, 2010.

[61] N. Bolong, A.F. Ismail, M.R. Salim and T. Matsuura, "A review of the effects of emerging contaminants in wastewater and options for their removal", Desalination, Vol. 239, pp. 229-246, 2009.

[62] G.M. Shaul, T.J. Holdsworth, C.R. Dempsey and K.A. Dostal, "Fate of water soluble azo dyes in the activated sludge process", Chemosphere, Vol. 22, pp. 107-119, 1991.

[63] M. Petrovi, S. Gonzalez and D. Barceló, "Analysis and removal of emerging contaminants in wastewater and drinking water", TrAC Trends in Analytical Chemistry, Vol. 22, pp. 685-696, 2003.

[64] S. Gonzalez, M. Petrovic and D. Barcelo, "Removal of a broad range of surfactants from municipal wastewater-Comparison between membrane bioreactor and conventional activated sludge treatment", Chemosphere, Vol. 67, pp. 335-343, 2007.

[65] T.A. Peters, "Purification of landfill leachate with reverse osmosis and nanofiltration", Desalination, Vol. 119, pp. 289-293, 1998.

[66] C.Y. Tang, Q.S. Fu, A.P. Robertson, C.S. Criddle and J.O. Leckie, "Use of reverse osmosis membranes to remove perfluorooctane sulfonate (PFOS) from semiconductor wastewater", Environmental Science \& Technology, Vol. 40, pp. 73437349, 2006.

[67] J. Radjenovic, A. Bagastyo, R.A. Rozendal, Y. Mu, J. Keller and K. Rabaey, "Electrochemical oxidation of trace organic contaminants in reverse osmosis concentrate using $\mathrm{RuO}_{2} / \mathrm{IrO}_{2}$-coated titanium anodes", Water Research, Vol. 45, pp. 1579-1586, 2011.

[68] G.-W. Cheng, W.-Y. Wei, Z.-C. Wu, F.-J. Zhang and X.-F. Huang, A study on degradation of organic contaminants of the A/O process of denitrogenation enhanced by zeolite and chemical phosphorus removal, In: International Conference on Energy and Environment Technology, Guilin, Guangxi 2009. 
[69] S. Zodi, J.-N. Louvet, C. Michon, O. Potier, M.-N. Pons, F. Lapicque and J.-P. Leclerc, "Electrocoagulation as a tertiary treatment for paper mill wastewater: Removal of non-biodegradable organic pollution and arsenic", Separation and Purification Technology, Vol. 81, pp. 62-68, 2011.

[70] D. Stalter, A. Magdeburg, M. Wagner and J. Oehlmann, "Ozonation and activated carbon treatment of sewage effluents: Removal of endocrine activity and cytotoxicity", Water Research, Vol. 45, pp. 1015-1024, 2011.

[71] D. Mohan, K.P. Singh and V.K. Singh, "Wastewater treatment using low cost activated carbons derived from agricultural byproducts-A case study", Journal of Hazardous Materials, Vol. 152, pp. 1045-1053, 2008.

[72] V.K. Gupta and Suhas, "Application of low-cost adsorbents for dye removal - A review", Journal of Environmental Management, Vol. 90, pp. 2313-2342, 2009.

[73] S.M.A. Salman, "The Helsinki Rules, the UN watercourses convention and the Berlin rules: Perspectives on international water law", Water Resources, Vol. 23, pp. 625640, 2007. 


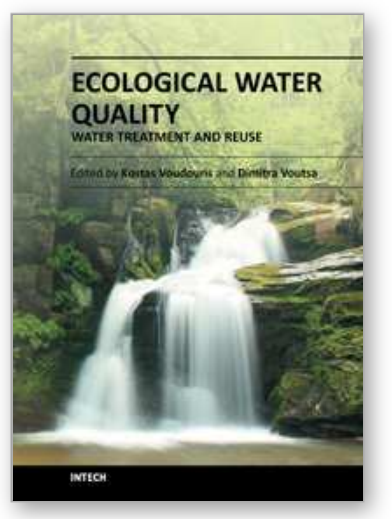

\author{
Ecological Water Quality - Water Treatment and Reuse \\ Edited by Dr. Voudouris
}

ISBN 978-953-51-0508-4

Hard cover, 496 pages

Publisher InTech

Published online 16, May, 2012

Published in print edition May, 2012

This book attempts to cover various issues of water quality in the fields of Hydroecology and Hydrobiology and present various Water Treatment Technologies. Sustainable choices of water use that prevent water quality problems aiming at the protection of available water resources and the enhancement of the aquatic ecosystems should be our main target.

\title{
How to reference
}

In order to correctly reference this scholarly work, feel free to copy and paste the following:

M. Mosharraf Hossain, K. M. Nazmul Islam and Ismail M. M. Rahman (2012). An Overview of the Persistent Organic Pollutants in the Freshwater System, Ecological Water Quality - Water Treatment and Reuse, Dr. Voudouris (Ed.), ISBN: 978-953-51-0508-4, InTech, Available from:

http://www.intechopen.com/books/ecological-water-quality-water-treatment-and-reuse/an-overview-of-thepersistent-organic-pollutants-in-the-freshwater-system

\section{INTECH}

open science | open minds

\section{InTech Europe}

University Campus STeP Ri

Slavka Krautzeka 83/A

51000 Rijeka, Croatia

Phone: +385 (51) 770447

Fax: +385 (51) 686166

www.intechopen.com

\section{InTech China}

Unit 405, Office Block, Hotel Equatorial Shanghai

No.65, Yan An Road (West), Shanghai, 200040, China

中国上海市延安西路65号上海国际贵都大饭店办公楼 405 单元

Phone: +86-21-62489820

Fax: $+86-21-62489821$ 
(C) 2012 The Author(s). Licensee IntechOpen. This is an open access article distributed under the terms of the Creative Commons Attribution 3.0 License, which permits unrestricted use, distribution, and reproduction in any medium, provided the original work is properly cited. 